\title{
Connective processing by bilingual children and monolinguals with specific language impairment: distinct profiles*
}

WILLEM M. MAK

Utrecht University

ELENA TRIBUSHININA

Utrecht University

JULIA LOMAKO

ZAS Berlin

NATALIA GAGARINA

$Z A S$ Berlin

\author{
EKATERINA ABROSOVA \\ Herzen State Pedagogical University of Russia
}

A ND

TED SANDERS

Utrecht University

(Received 20 Fune 2014-Revised 8 March 2015-Accepted I6 December 2015First published online 5 February 2016)

ABSTRACT

Production studies show that both Russian-speaking children with specific language impairment (SLI) and bilingual children for whom Russian is a non-dominant language have difficulty distinguishing between the near-synonymous connectives $i$ 'and' and $a$ 'and/but'. $I$ is a preferred connective when reference is maintained, whereas $a$ is

[*] We thank the action editor and the anonymous reviewers for their useful comments. We are also grateful to all children, parents, and teachers who have made this investigation possible. This research was supported by a Marie Curie International Research Staff Exchange Scheme Fellowship within the 7th European Community Framework Programme (grant number 269173). Address for correspondence: Dr W. M. Mak, Utrecht Institute of Linguistics, Trans Io, 35 I2 JK Utrecht, The Netherlands. tel: +3r302539i52; e-mail: w.m.mak@uu.nl 
normally used for reference shift. We report an eye-tracking experiment comparing connective processing by Russian-speaking monolinguals with typical language development (TLD) with that of RussianDutch bilinguals and Russian-speaking monolinguals with SLI (age 5-6). The results demonstrate that the processing profiles of monolinguals with TLD and bilinguals are similar: both groups use connective semantics immediately for predicting further discourse. In contrast, children with SLI do not show sensitivity to these semantic differences. Despite similar production profiles, bilinguals and monolinguals with SLI are clearly different in connective processing. We discuss the implications of these results for the possible causes of the errors in the two populations.

\section{INTRODUCTION}

\section{Bilingualism and specific language impairment}

Multilingual children constitute a growing population in Europe. Many of these children lack age-appropriate language skills (in one or both languages) due to various factors, including insufficient exposure, non-native input, and cross-linguistic influence. The complexity of factors which have an impact on bilingual language development and lack of acquisition standards for bilingualism lead to difficulties in assessing bilingual children with insufficient language development and to the misdiagnosis of bilingual children for specific language impairment (SLI) (Armon-Lotem, De Jong \& Meir, 20ı5; Bedore \& Peña, 2008; Genesee, Paradis \& Crago, 2004). It has often been noticed in the literature that young second language (L2) learners display specific similarities with monolingual children with SLI in language production (Armon-Lotem, 20ı4; Blom, De Jong, Orgassa, Baker \& Weerman, 20ı3; Crago \& Paradis, 2003; Paradis, I 999, 2010b; Paradis \& Crago, 2000; Paradis, Rice, Crago \& Marquis, 2008; inter alia). Not only early sequential bilinguals but also simultaneous bilinguals growing up with two languages from birth may experience serious difficulties, especially in their non-dominant (weaker) language in which they get less input and little or no schooling (Meisel, 2007; Schlyter, I 993; Schlyter \& Håkansson, I 994).

Most of the studies trying to disentangle the effects of bilingualism and SLI deal with morphosyntactic aspects of language and predominantly focus on language production. However, it is plausible that apparently similar profiles of bilinguals and children with SLI have different underlying causes. For example, Chondrogianni and Marinis (2012) found that Turkish-English sequential bilinguals are sensitive to ungrammaticality of morpheme omission regardless of their variable performance on the production of tense morphemes. In the same vein, 
Paradis et al. (2008) report that L2 children's performance on a conscious judgement task is better than their morpheme production. Children with SLI make errors in production as well, but, unlike bilinguals, they fail to grasp ungrammaticality in a receptive task (Montgomery \& Leonard, I 998, 2006).

In view of these findings, it is possible that the profiles of bilingual children and children with SLI in language processing are not similar. In this paper we test this hypothesis by comparing the processing of discourse connectives by Russian-speaking children with SLI and Russian-Dutch simultaneous bilinguals raised in the Netherlands.

\section{Production of Russian additive connectives across populations}

Prior research on connective production demonstrates that monolingual Russian-speaking children with SLI (Gagarina, 2012; Tribushinina, Dubinkina \& Sanders, 20I5), Russian-German early sequential bilinguals (Tribushinina, Valcheva \& Gagarina, in press), and Russian-Dutch simultaneous bilinguals (Tribushinina, Mak, Andreiushina, Dubinkina \& Sanders, 20 I5) have difficulty distinguishing between two Russian additive connectives $-i$ 'and' and $a$ 'and/but' - in narrative production. When used for clausal coordination, these two connectives have subtle semantic differences that are crucial in terms of discourse organization (Jasinskaja \& Zeevat, 2008, 2009; Kreidlin \& Paducheva, I974). I 'and' is used by default in cases of reference maintenance as in (I), while $a$ 'and/but' is used to mark reference shift as in (2).

( I) Ptica vernulas' v gnezdo, i (ona) pokormila ptencov.

bird came.back in nest-ACC and (she) fed nestlings-ACC

'The bird returned to the nest, and (she) fed the nestlings.'

(2) Ptica iskala edu, a ptency spali v gnezde.

bird searched food-ACC and/but nestlings slept in nest-LOC

'The bird was searching for food, and/but the nestlings were sleeping in the nest.'

Yet, $i$ 'and' is also used when reference is shifted when there is an obligatory causal relation between the two clauses as in (3) or overall similarity as in (4). When there is no plausible causal relationship between the propositions, as in (2), $i$ cannot be used in contexts of reference shift.

(3) Ptica vernulas' v gnezdo, i ptency očen' obradovalis'.

bird came.back in nest-ACC and nestlings very became.glad

'The bird returned to the nest, and the nestlings were very happy.'

(4) Ptica ljubit červjačkov, i ptency tože ljubjat červjačkov.

bird likes worms-ACC and nestlings too like worms-ACC

'The bird likes worms, and the nestlings also like worms.' 
Similarly, $a$ 'and/but' can only be used for maintenance if there is a contrast relation between the clauses as in (5).

(5) Dnëm ptency učatsja letat', a nočju oni spjat.

by.day nestlings learn fly and/but at.night they sleep

'During the day the nestlings learn to fly, and/but at night they sleep.'

The results of an eye-tracking experiment reported in Mak, Tribushinina, and Andreiushina (2013) demonstrate that adult speakers of Russian use the semantic information in the additive connectives to predict discourse continuation. The participants in their experiment were more likely to switch gaze to another referent after $a$ 'and/but' than after $i$ 'and', even before they heard the second clause. No such difference was found for Dutch, where both en 'and' and maar 'but' can be felicitously used for reference maintenance and shift without any constraints (like the English counterparts and and but).

In view of the intricate discourse-organizational profiles and subtle semantic differences between $i$ 'and' and $a$ 'and/but', it is not surprising that the acquisition of these connectives has a protracted timecourse. Even though additives are the least conceptually complex connective type (Evers-Vermeul \& Sanders, 2009) and even though $i$ 'and' and $a$ 'and/but' are the most frequent Russian connectives and the first ones to emerge in child speech (Knjazev, 2007), even seven-year-old monolinguals with typical language development (TLD) sometimes incorrectly use $a$ instead of $i$, and vice versa. Since there is no one-to-one mapping between type of referential development (maintenance or shift) and connective ( $i$ or $a$ ), children have to find out that the two connectives have underlying semantic preferences and that violating these preferences is only possible under specific constraints, such as an obligatory causal reading of $i$ (in cases of shift) and contrast for $a$ (in cases of maintenance).

Children with SLI and bilingual children for whom Russian is a non-dominant language have even more trouble differentiating between the two connectives. Based on error rates, we cannot distinguish between monolinguals with SLI and bilinguals; both groups make significantly more errors than monolinguals with TLD (Tribushinina, Mak et al., 2015). Furthermore, the error types are also similar in these two populations. Both monolinguals with SLI and bilinguals with TLD incorrectly use $i$ for reference shift in the absence of any plausible causal relation. In the study reported by Tribushinina, Mak et al., Russian-Dutch bilinguals made this error in $40 \%$ of contexts where $i$ was used for reference shift (meaning that in the remaining $60 \%$ of contexts there was a plausible causal relation licensing the use of $i$ for reference shift). The children with SLI made this error in $31 \%$ of the cases of $i$ in shift-contexts. Another common error type involves the use 
of $a$ in shift-contexts where an obvious causal link must be marked by $i$ ( $38 \%$ of shift-contexts in the bilingual group and $44 \%$ in the SLI group). In addition, both groups sometimes erroneously use $a$ for reference maintenance in the absence of a contrastive relation, but these errors are relatively infrequent in both groups. In summary, both Russian monolinguals with SLI and Dutch-dominant bilinguals often confuse $i$ and $a$ in production: based on error rates and error types we cannot differentiate between the two groups.

\section{The present study}

Production studies show that both bilingual children and monolingual children with SLI make more errors with $i$ 'and' and $a$ 'and/but' than their monolingual peers with TLD. In the present study, we investigate what this means for the processing profiles of these three groups. We performed an eye-tracking experiment by means of the visual world paradigm, using the procedure developed by Mak et al. (2013). In this procedure, participants see two pictures, accompanied by two sentences presented auditorily. The subject of the first sentence refers to one of the pictures. The second sentence starts either with the connective $i$ 'and' or with the connective $a$ 'and/but'. Since monolinguals with TLD perform relatively well in the production of the connectives, we expect that they can predict the upcoming referent based on connective semantics. Hence, we predict more gaze switches to the referent after $a$ 'and/but' than after $i$ 'and', before the second clause is introduced, as was the case with the adult participants in Mak et al.

The high error rate for the other two groups of children may imply that these groups of children have not acquired the semantics of the connectives. However, an alternative explanation of the error rates may be that the children have difficulty using the semantic distinction in production, even though they do know the difference between the connectives. Hence, these children may actually use the semantic information in processing, in spite of the high error rate in production.

\section{METHOD}

\section{Participants}

Seventy-two children participated in this study: twenty-three RussianDutch bilinguals ( 5 female, mean age: 5;9, age range: 5;0-6; I I), twentynine Russian monolinguals with TLD (2 I female, mean age: 5; I0, age range: 5;2-6;7), and twenty Russian monolinguals with SLI (8 female, mean age: $6 ; 3$, age range: 5;2-6;7). One bilingual child did not finish the experiment and was excluded from the analysis. It was decided to match the groups for chronological age rather than language scores. If younger children with TLD were included as a comparison group for children with 
SLI, they would be less cognitively advanced compared to the SLI group, and therefore less able to understand the conceptual relations expressed by the connectives (Boudreau \& Chapman, 2000).

The bilingual participants were recruited from the Russian Saturday school in Amersfoort (the Netherlands). They were all dominant in Dutch. Dominance was determined by the amount of exposure to each of the languages (Argyri \& Sorace, 2007; Döpke, I992). All the bilingual participants included in this study were born in the Netherlands and raised bilingual from birth (in most cases by a Russian mother and a Dutch father). They all attended a regular Dutch primary school and a Russian language school on Saturday morning. The participants had normal sensorimotor, social-emotional, and cognitive development (as reported by teachers and parents).

The monolingual participants with SLI were recruited through special kindergartens for language disorders in St Petersburg. The children were monolingual speakers of Russian and had been independently diagnosed for SLI (in Russian - obščee nedorazvitie reči II-III urovnja) by a multidisciplinary committee consisting of a speech pathologist, a psychiatrist, a neurologist, a paediatrician, and a clinical psychologist. The children selected for the study met the following selection criteria: normal IQ, absence of any other known disorder such as autism, no evidence of neurological impairment, no severe visual or auditory problems (based on the yearly medical checks at the kindergarten), and normal motor, socialemotional, and cognitive development.

Russian monolinguals with TLD were recruited from a regular kindergarten in St Petersburg. The participants were selected following a set of criteria: normal IQ and normal motor, social-emotional, and cognitive development, as well as age-appropriate language skills (as reported by teachers and parents). Informed consent was obtained from the parents of all participants.

\section{Materials}

We used the same materials as Mak et al. (2013). These consisted of twenty-eight items, of four types. All items consisted of a display with two animals. The display was accompanied by a set of two spoken clauses. Examples of these sets of clauses are given in Table I. There were two conditions - clauses conjoined by $i$ and clauses conjoined by $a$. To make sure that the listeners would not be able to predict what the referential relation between the clauses would be on the basis of the materials, the second clause of a set either referred to the same referent as the first clause (sentence types I and 2) or referred to a different referent (switch conditions, sentence types 3 and 4 ). 
TABLE I. Example sentences

\begin{tabular}{|c|c|c|}
\hline Sentence type & Russian sentence & English translation \\
\hline $\begin{array}{l}\text { I. Maintenance, } \\
\text { connective } i\end{array}$ & $\begin{array}{l}\text { Obezjana begaet } \mathrm{v} \text { parke, } \mathrm{i} \text { ona } \\
\text { takže plavaet } \mathrm{v} \text { bassejne. }\end{array}$ & $\begin{array}{l}\text { Monkey runs in the park and she also } \\
\text { swims in the swimming pool. }\end{array}$ \\
\hline $\begin{array}{l}\text { 2. Maintenance, } \\
\text { connective } a\end{array}$ & $\begin{array}{l}\text { Lev zimoj vsegda kataetsja na } \\
\text { lyžax, a letom on vsegda } \\
\text { plavaet v reke. }\end{array}$ & $\begin{array}{l}\text { Lion always goes skiing in the winter, } \\
\text { and/but in the summer he always goes } \\
\text { swimming in the river. }\end{array}$ \\
\hline $\begin{array}{l}\text { 3. Switch, } \\
\text { connective } i\end{array}$ & $\begin{array}{l}\text { Ovečka ljubit pit' moloko, i } \\
\text { Svinja tože ljubit pit' } \\
\text { moloko. }\end{array}$ & $\begin{array}{l}\text { Sheep likes milk, and Pig also likes } \\
\text { milk. }\end{array}$ \\
\hline $\begin{array}{l}\text { 4. Switch, } \\
\text { connective } a\end{array}$ & $\begin{array}{l}\text { Korova ljubit tancevat', a Kot } \\
\text { ljubit pet'. }\end{array}$ & $\begin{array}{l}\text { Cow likes dancing, and/but Cat likes } \\
\text { singing. }\end{array}$ \\
\hline
\end{tabular}

The sentences were recorded by a female native speaker of Russian. The sound files were manipulated in such a way that the connective started four seconds after the beginning of the trial and the second clause started five seconds after the beginning of the trial. In this way we ensured the participants had one second to react to the connective before the second sentence started. The naturalness of the sentences was not affected because a post-conjunctional silence is a pervasive phenomenon in spoken language (e.g. Hawkins, I97 ; Schilperoord, r 996; Swerts, I 998).

Fourteen pictures of animals were used in the experiment. For each sentence type these pictures were combined in seven pairs. Throughout the experiment, an animal sometimes was and sometimes was not mentioned as the referent of the first clause. The pictures of the animals were presented as in Figure I. The referent of the first clause was sometimes presented on the left, in other cases it was presented on the right of the screen. A pair of animals did not appear twice. The sentence types were pseudo-randomly ordered.

\section{Apparatus}

In the Netherlands, the experiment was run on a Tobii I 750 eye-tracker, sampling at $50 \mathrm{~Hz}$ (every $20 \mathrm{~ms}$ ). The items were presented on a $\mathrm{I} 7$-inch monitor via a computer running the Tobii's Clearview software. In Russia, the experiment was run on a Tobii T6o eye-tracker, sampling at $60 \mathrm{~Hz}$ (every I6.6 ms) using Tobii Studio. The items were presented on a I7-inch monitor.

\section{Procedure}

The children were tested individually in a quiet room at their school/ kindergarten. They were simply asked to look at the pictures on the screen and listen to the sentences. After the calibration the experiment started. The whole experiment took about 5 minutes. 

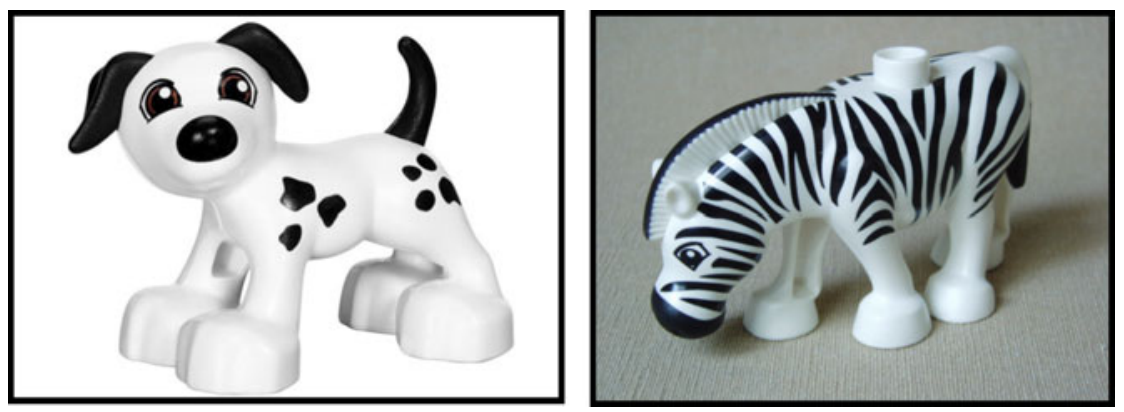

Fig. I. Example of a visual stimulus (Zebra nikogda ne byla v Rossii, $i$ Sobaka tože nikogda ne byla v Rossii 'Zebra has never been to Russia, and Dog has also never been to Russia').

\section{Analysis}

From the eye-tracking record we determined the position of the eye in roo-ms steps. The final dataset was analyzed by means of a multilevel logistic regression (Goldstein, I 999; Mirman, Dixon \& Magnuson, 2008) in R using the lme4 package (Bates, Maechler \& Bolker, 20I3). This way, we treated the eye-tracking data for each trial as longitudinal data. A logistic regression characterizes the data as binomial in that every $100 \mathrm{~ms}$ the participant can fixate on either picture, allowing us to assess the probability of looks to a picture over time (if the participant fixated elsewhere, the data were not included for analysis). By using a multilevel approach, we can take into account the nested nature of the data: Trials were nested within items and within subjects.

Using the multilevel logistic regression analysis, we modelled the probability of fixation on the target picture as a function of three predictors: Group (monolinguals with TLD vs. bilinguals vs. monolinguals with SLI), Connective ( $i$ vs. $a$ ), and Time. Subjects and items were added as random factors (for a similar approach see Trueswell $\&$ Papafragou, 2010). Since the fit of the models increased when we added random slopes, these were also included.

We started with a base model with only the random effects. We then added the fixed effects of Time, Group, and Connective. Finally, the interaction of Time and Connective was added. Goodness of fit was computed to establish whether adding these components led to a better fit with the data. The analysis was done on the time interval between the beginning of the connective (at 4 seconds after item onset) until $200 \mathrm{~ms}$ after the beginning of the second sentence $(5 \cdot 2$ seconds after item onset). The total duration of the time window we analyzed was thus $1200 \mathrm{~ms}$. We added this extra 200 ms because it takes approximately that time to initiate and compute a saccade in reaction to the external input. Therefore, only $200 \mathrm{~ms}$ after the 
beginning of the second sentence can the looks reflect reaction to the word following the connective.

We expected that on hearing the first segment, the participants would look at the picture of the subject of the first segment. The participants then heard the connective. In the experiment of Mak et al. (2013), the (adult) participants showed a slight overall tendency to switch to the other picture when they heard the connective. Hence, in general we expected the proportion of fixations on the alternative picture to rise during the target interval, between the onset of the connective and the onset of the remainder of the second segment, resulting in an effect of Time.

However, if the participants use the semantics of the connectives, we expected that they would switch more on hearing the connective $a$ 'and/ but' than on hearing the connective $i$ 'and'. In the time interval between the onset of the connective and the onset of the subject of the second segment, we expected the proportion of looks on the alternative picture to increase faster after $a$ than after $i$. Hence we expected an interaction of Time and Connective on the proportion of looks on the alternative if the participants were aware of the semantic differences between the connectives. In the model, the condition with the connective $i$ for the monolinguals with TLD was taken as the baseline. The other conditions were compared within the model with this baseline.

\section{RESULTS}

The data are presented in Figure 2. The model including the main effects of Group, Time, and Connective showed a better fit than the base model $\left(\chi^{2}(4)\right.$ $=702.58, p<.00 \mathrm{I})$. Adding the interactions again significantly increased the fit of the model $\left(\chi^{2}(7)=222 \cdot 94, p<.001\right)$. In Table 2 the latter model is presented.

The model shows that there is an interaction of Time and Connective for the monolinguals with TLD. There is a linear increase in the looks at the alternative picture for the connective $i$, but this increase is stronger for $a$. This interaction is different both for the bilinguals and for the monolinguals with SLI. Therefore, separate models were computed for these two groups to determine whether there is an interaction for these two groups too. The results of these models are presented in Table 3 .

For the bilinguals there was an interaction of Time and Connective: the increase in looks at the alternative picture was stronger in the condition with the connective $a$ than in the condition with the connective $i$. For the monolinguals with SLI no interaction was found. There was no difference between the connectives in the increase in looks at the alternative picture.

In order to interpret the results in the target region, we need to make sure that there is no general processing difference between the groups (Windsor, 

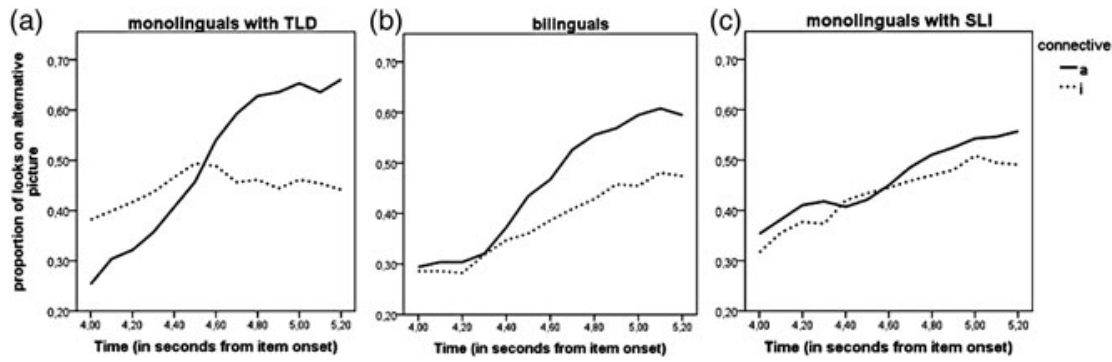

Fig. 2. The proportion of looks on the alternative picture over time, split by connective. Panel A presents the results of the monolinguals with TLD, panel B of the bilinguals, and panel $\mathrm{C}$ of the monolinguals with SLI

TA B LE 2. Fixed effects from the best-fitting multilevel logistic regression model of the data from the connective region

\begin{tabular}{|c|c|c|c|c|}
\hline & $\beta$ & $S E$ & $z$ & $p$ \\
\hline Intercept & $-I \cdot I 59$ & 0.393 & $-2 \cdot 943$ & .003 \\
\hline Connective(a) & $-6 \cdot 93 \mathrm{I}$ & 0.562 & $-12 \cdot 328$ & $<.001$ \\
\hline Time & 0.198 & 0.078 & $2 \cdot 506$ & .012 \\
\hline Connective(a)*Time & $\mathrm{I} \cdot 55^{6}$ & O. I I 6 & I 3.423 & .001 \\
\hline Group(BI) & -3.367 & 0.584 & $-5 \cdot 768$ & $<.001$ \\
\hline Group(BI)*Connective(a) & 4.737 & 0.824 & $5 \cdot 750$ & $<.001$ \\
\hline Group(BI)*Time & 0.676 & $0.12 \mathrm{I}$ & $5 \cdot 570$ & $<.001$ \\
\hline Group (BI)*Connective (a)*Time & $-I \cdot 009$ & 0.175 & $-5.76 \mathrm{I}$ & $<.00 \mathrm{I}$ \\
\hline Group(SLI) & $-2 \cdot 185$ & 0.590 & -3.706 & $<.001$ \\
\hline Group(SLI)*Connective(a) & $6 \cdot 587$ & 0.828 & $7 \cdot 596$ & $<.001$ \\
\hline Group(SLI)*Time & 0.464 & 0.123 & 3.784 & $<.001$ \\
\hline Group(SLI)*Connective(a)*Time & $-I \cdot 452$ & 0.176 & $-8 \cdot 248$ & $<.00 \mathrm{I}$ \\
\hline
\end{tabular}

NOTES: $\mathrm{BI}=$ bilingual children; $\mathrm{SLI}=$ children with SLI.

TABLE 3. Fixed effects from the separate models for the bilinguals and the children with SLI

\begin{tabular}{lrrrr}
\hline & $\beta$ & $S E$ & $z$ & \multicolumn{1}{c}{$p$} \\
\hline Bilinguals & & & & \\
Intercept & -4.599 & 0.462 & -9.949 & $<.0$ I \\
Connective(a) & -2.200 & 0.644 & $-3.4 \mathrm{I} 7$ & $<.0 \mathrm{I}$ \\
Time & 0.886 & 0.093 & 9.546 & $<.00 \mathrm{I}$ \\
Connective(a)*Time & 0.553 & $0 . \mathrm{I} 32$ & 4.175 & $<.0 \mathrm{I}$ \\
Children with SLI & & & & $<.00 \mathrm{I}$ \\
Intercept & -3.443 & 0.476 & -7.237 & .636 \\
Connective(a) & -0.313 & 0.662 & -0.474 & $<.00 \mathrm{I}$ \\
Time & 0.680 & 0.095 & 7.159 & .462 \\
Connective(a)*Time & 0.099 & 0.134 & 0.735 & \\
\hline
\end{tabular}


2002; Windsor, Milbrath, Carney \& Rakowski, 200I). Therefore we analyzed the gaze data of the first sentence. These results are presented in Figure 3. On hearing the subject of the first sentence, the children were expected to look at the picture corresponding to the subject, and hence to look away from the alternative picture. If there is a difference between the groups in the general speed with which the participants look at the picture in reaction to the noun, this should be measurable in this time frame. Hence we performed an analysis in which we looked at the effect of Time (the first 4 seconds) and Group (monolinguals with TLD versus monolinguals with SLI versus bilinguals).

The monolinguals with TLD were taken as the baseline for the factor Group. The model including the main effects provided a better fit of the data than the base model $\left(\chi^{2}(3)=2406 \cdot 3, p<\cdot 00 \mathrm{I}\right)$. Adding the interaction did not improve the model further $\left(\chi^{2}(2)=0.50, p=.78\right)$ compared to the model with the main effects. The results of the latter model are presented in Table 4. There was a main effect of Time: the proportion of looks at the alternative picture decreased during the first sentence.

\section{DISCUSSION AND CONCLUSION}

This study compared the processing of discourse connectives by monolingual children with and without SLI, and simultaneous bilinguals in their non-dominant language. Earlier production studies demonstrate that both bilingual children for whom Russian is a non-dominant language and monolinguals with SLI often make errors in production by confusing $i$ 'and' and $a$ 'and/but' (Gagarina, 20 I2; Tribushinina, Dubinkina \& Sanders, 2015; Tribushinina, Mak et al., 20I5). In this paper, we investigated whether these seemingly similar production profiles are associated with similar processing profiles.

Like the adults in an earlier experiment (Mak et al., 2013), the children in this study showed a slight overall tendency to switch to the other picture upon hearing the connective. However, only children with TLD-both monolingual and bilingual - reacted differentially to $i$ and $a$. In these two groups, there was a greater increase in the proportion of looks to the other referent after $a$ (shift marker) than after $i$ (maintenance marker) in the time interval between the onset of the connective and the onset of the subject of the second clause. In contrast, in the SLI group, the increase in the proportion of looks to the other picture was not different for $i$ and $a$.

Based on errors in connective production attested in earlier research (Tribushinina, Mak et al., 20I5), we cannot differentiate between bilinguals with TLD and monolinguals with SLI. However, as demonstrated by the current results, the two groups clearly have different profiles in processing. Unlike children with SLI, bilinguals are more likely 


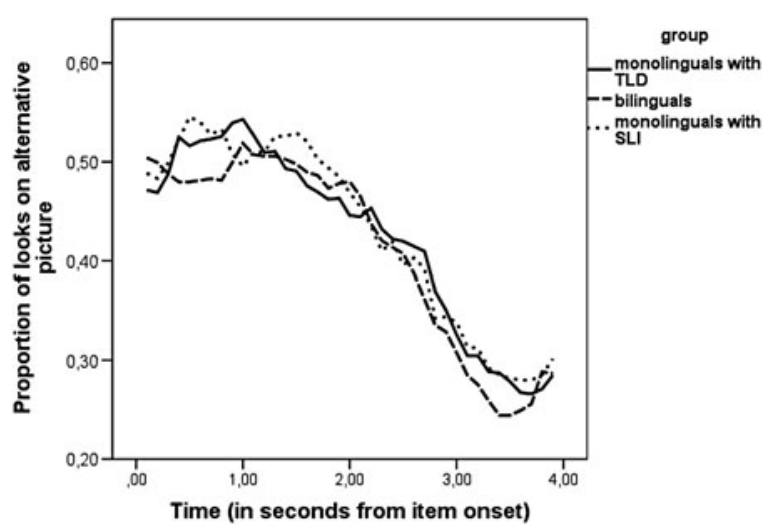

Fig. 3. The proportion of looks on the alternative picture during the first sentence, split by group.

TA В LE 4. Fixed effects from the best fitting model of the data of the first clause

\begin{tabular}{lrrrr}
\hline & \multicolumn{1}{c}{$\beta$} & \multicolumn{1}{c}{$S E$} & \multicolumn{1}{c}{$p$} \\
\hline Intercept & $0.33 \mathrm{I}$ & 0.078 & 4.27 & $<.00 \mathrm{I}$ \\
Bilinguals & $-0.06 \mathrm{I}$ & 0.057 & $-\mathrm{I} \cdot 08$ & .28 \\
Children with SLI & 0.022 & 0.059 & 0.39 & .70 \\
Time & -0.328 & 0.007 & -48.32 & $<.00 \mathrm{I}$ \\
\hline
\end{tabular}

to shift gaze to another referent after $a$ than after $i$. Thus, like the adults in Mak et al. (2013) and the monolingual children with TLD in the present study, Russian-Dutch bilinguals, for whom Russian is a non-dominant language, are able to use the semantic information in the connective to predict how discourse will unfold.

This means that the high error rates in connective production by RussianDutch bilinguals (Tribushinina, Mak et al., 20 I 5) are not due to insufficient or deviant knowledge of connective semantics. As shown by the current results, bilinguals do know the relevant difference between $i$ and $a$. A possible cause of these production errors is cross-linguistic influence from their dominant language (Dutch), where the additive connectives en 'and' and maar 'but' can be used for reference maintenance and shift without any constraints. By way of illustration, consider the following fragment from a narrative produced by a five-year-old Russian-Dutch bilingual:

(6) Vorona rybu vzjala i kušaet. Lisa prišla i uvidela. I vorona sidit na dereve. 
crow fish-ACC took and eats. Fox came and saw. And crow sits on tree-LOC

'The crow grabbed the fish and is eating. The fox came and saw (it). And the crow is sitting in the tree.'

In this fragment, the child erroneously uses $i$ 'and' rather than $a$ 'and/but' in the context of reference shift to coordinate discourse segments that are not causally related. Notice that the Dutch counterpart en 'and' is perfectly acceptable in this case. Such errors - that persist in production at least until age eight (Tribushinina, Mak et al., 2015)-may be seen as an instance of 'covert code-switching', i.e. activating structural properties of the other language, without inserting lexical material from that language (Meisel, 2007). The inhibition of the other language is never complete (Hulk, 2000), and it is harder to inhibit the dominant language (Argyri \& Sorace, 2007). This may explain the fact that Dutch-dominant bilinguals sometimes use the Russian connectives 'the Dutch way', even though they know the difference between the Russian additives. If this explanation is on the right track, it would mean that cross-linguistic influence - at least in the domain of discourse connectives-does not pertain to the level of representation and may be ascribed to inhibition problems in production, which is a more complex task than a receptive task (cf. Chondrogianni \& Marinis, 2012). To further investigate the influence of competition cost on language production by bilinguals, future research may relate error rates to measures such as working memory and inhibitory control.

Thus, the processing difference between $i$ and $a$ for the bilingual children shows that, in spite of the fact that they make many errors in production, they do know the distinction between the connectives and use it to predict the upcoming referent. Children with SLI also make many errors in production but, unlike the bilingual children, in our processing data they show no evidence of knowing the connectives. This suggests that children with SLI make errors in production because they have not yet acquired the relevant semantic differences between $i$ and $a$. This interpretation is consistent with earlier findings demonstrating that individuals with SLI show poor performance not only in production, but also in grammaticality judgement tasks (Chondrogianni \& Marinis, 2012; Montgomery \& Leonard, I998, 2006; Paradis, 2010a; Paradis et al., 2008), which points at delayed or incomplete acquisition of grammatical phenomena. Furthermore, children with SLI are known to have poor semantic representations of words in the mental lexicon (Alt, Plante \& Creusere, 2004; Befi-Lopes, Silva \& Bento, 2010; Chaix, Barry \& Duvignau, 2012; Gray, 2005; McGregor \& Appel, 2002; Nash \& Donaldson, 2005; Sheng \& McGregor, 2010), which is again consonant with the idea that our participants with SLI did not have the same 
semantic representations of the additive connectives as their unimpaired peers.

Notice, however, that the current results are also compatible with alternative explanations. First of all, it is possible that the children with SLI do use the semantics of the connective to predict the upcoming referent, but that such an effect would be visible later in the timecourse. We could not investigate that in the data of our experiment, because the connective is followed by a constituent (mostly the subject of $\mathrm{S}_{2}$ ) that guides the children to the correct referent.

It has been shown that children with SLI have longer reaction times in a variety of (linguistic and non-linguistic) cognitive tasks, such as tapping, visual search, mental rotation, picture matching, and grammaticality judgement and phonological awareness tasks (see Windsor, 2002; Windsor et al., 200I, for an overview). If such slower responses reported in prior research are due to overall slower processing speed in SLI, it might be the case that it also takes children with SLI more time to shift their gaze in a visual world paradigm-task. However, our finding that children with SLI were as fast as their peers with TLD in shifting their gaze to the referent of the subject NP shows that this is not in general the case. Similar results were reported by Andreu, Sanz-Torrent, and Trueswell (2013), who measured children's ability to look at the object of a sentence on the basis of verb semantics (e.g. shift gaze to the picture of a cow on the basis of the sentence The man milks ...). They showed that children with TLD and with SLI had a similar pattern in their looking behaviour. The difference in the timecourse of the effect would thus be attributable to a specific problem the children have with the connectives, instead of a general different processing pattern.

A second possibility is that the children with SLI do know the difference between the connectives but are not able to use this knowledge for predicting upcoming referents. Importantly, the findings by Andreu et al. (2013) show that children with SLI predict the object on the basis of verb meaning. The looks at the object of the verb (e.g. the picture of a cow) increased well before the children heard the object noun phrase (e.g. the word cow). This implies that, in general, children with SLI are capable of predicting an upcoming referent based on the semantics of the word currently being processed. Thus, the difference in processing patterns between the children with SLI and the children with TLD is not due to a general difficulty with predicting upcoming linguistic input. The comparison of our findings and those reported by Andreu et al. (2013) suggests that individuals with SLI may have particular difficulty processing function words (such as connectives), which is perfectly explicable given the fact that function words have more abstract and more complex meanings than content words (such as verbs). 
In summary, the present study has shown that, at least in the domain of discourse connectives, bilinguals with TLD and monolinguals with SLI have different processing profiles despite similar production profiles. Further research is necessary in order to find out if processing measures can actually be used (in clinical practice) for differentiating between bilinguals with TLD and children with SLI.

\section{REFERENCES}

Alt, M., Plante, E. \& Creusere, M. (2004). Semantic features in fast-mapping: performance of preschoolers with specific language impairment versus preschoolers with normal language. Fournal of Speech, Language, and Hearing Research 47, 407-20.

Andreu, L., Sanz-Torrent, M. \& Trueswell, J. C. (2013). Anticipatory sentence processing in children with specific language impairment: evidence from eye movements during listening. Applied Psycholinguistics 34, 5-44.

Argyri, E. \& Sorace, A. (2007). Crosslinguistic influence and language dominance in older bilingual children. Bilingualism: Language and Cognition ro, 79-99.

Armon-Lotem, S. (2014). Between L2 and SLI: inflections and prepositions in the Hebrew of bilingual children with TLD and monolingual children with SLI. Fournal of Child Language 4r, 3-33.

Armon-Lotem, S., De Jong, J. \& Meir, N. (eds) (2015). Assessing multilingual children: disentangling bilingualism from language impairment (Communication Disorders across Languages, I 3). Bristol: Multilingual Matters.

Bates, D., Maechler, M. \& Bolker, B. (2013). lme4: linear mixed-effects models using $\mathrm{S}_{4}$ classes (R package version o.999999-2). Online: <http://CRAN.R-project.org/package= lme $>$.

Bedore, L. M. \& Peña, E. D. (2008). Assessment of bilingual children for identification of language impairment: current findings and implications for practice. International Fournal of Bilingual Education and Bilingualism II, I-29.

Befi-Lopes, D. M., Silva, C. P. F. \& Bento, A. C. P. (2010). Semantic representation and naming in children with specific language impairment. Pró-Fono Revista de Atualização Cientifica 22, I I $3-8$.

Blom, E., De Jong, J., Orgassa, A., Baker, A. \& Weerman, F. (2013). Verb inflection in monolingual Dutch and sequential bilingual Turkish-Dutch children with and without SLI. International Fournal of Language and Communication Disorders 48, 382-93.

Boudreau, D. \& Chapman, R. S. (2000). The relationship between event representation and linguistic skill in narratives of children and adolescents with Down Syndrome. Fournal of Speech, Language, and Hearing Research 43, I I 46-59.

Chaix, Y., Barry, I. \& Duvignau, K. (2012). Semantic approximation in SLI and normal development. Revue française de linguistique appliquée 1 7, 65-76.

Chondrogianni, V. \& Marinis, T. (2012). Production and processing asymmetries in the acquisition of tense morphology by sequential bilingual children. Bilingualism: Language and Cognition $\mathbf{1 5}, 5^{-2} \mathbf{1}$.

Crago, M. \& Paradis, J. (2003). Two of a kind? Commonalities and variation in languages and language learners. In Y. Levy \& J. Schaeffer (eds), Language competence across populations: towards a definition of specific language impairment (pp. 97-1 10). Mahwah, NJ: Lawrence Erlbaum Associates.

Döpke, S. (1992). One parent one language: an interactional approach. Amsterdam: John Benjamins.

Evers-Vermeul, J. \& Sanders, T. (2009). The emergence of Dutch connectives: how cumulative cognitive complexity explains the order of acquisition. Fournal of Child Language 36, 829-54. 
Gagarina, N. (2012). Elicited narratives of monolingual Russian-speaking preschoolers: a comparison of typically developing children and children with language disorders. In L. Szucsich, N. Gagarina, E. Gorishneva \& J. Leszkowicz (Eds), Linguistische Beiträge zur Slavistik. XIX. JungslavistInnen Treffen in Berlin, I6.-I8. Dezember 20IO (Specimina Philologiae Slavicae I 7 I), 7 I-90. München: Otto Sagner.

Genesee, F., Paradis, J. \& Crago, M. (2004). Dual language development and disorders: $a$ handbook on bilingualism and second language learning. Baltimore, MD: Brookes Publishing.

Goldstein, H. (I 999). Multilevel statistical models. London: Edward Arnold.

Gray, S. (2005). Word learning by pre-schoolers with specific language impairment: effect of phonological or semantic cues. Fournal of Speech, Language, and Hearing Research $\mathbf{4 8}$, I 452-67.

Hawkins, P. R. (r97I). The syntactic location of hesitation pauses. Language and Speech $\mathbf{1 4}$, $277-88$.

Hulk, A. (2000). Non-selective access and activation in child bilingualism: the syntax. In S. Döpke (ed.), Cross-linguistic structures in simultaneous bilingualism, 57-78. Amsterdam: John Benjamins.

Jasinskaja, E. \& Zeevat, H. (2008). Explaining additive, adversative and contrast marking in Russian and English. Revue de Sémantique et Pragmatique 24, 65-91.

Jasinskaja, E. \& Zeevat, H. (2009). Explaining conjunction systems: Russian, English, German. In A. Riester \& T. Solstad (eds), Proceedings of Sinn und Bedeutung I3 (pp. 23I-246). Stuttgart. Online: <http://www.uni-stuttgart.de/linguistik/sfb732/index.php? article_id= $\mathrm{I}$ IO $>$.

Knjazev, J. P. (2007). Ontogenez značenij obuslovlennosti [Ontogeny of causal meanings]. In S. N. Cejtlin (ed.), Semantičeskie kategorii $v$ detskoj reči [Semantic categories in child speech], 339-58. St Petersburg: Nestor-Istoriâ.

Kreidlin, G. E. \& Paducheva, E. V. (r 974). Značenie i sintaksičeskie svojstva soûza $A$ [Meaning and syntactic properties of the conjunction $A]$. Naučno-Tehničeskâ̂ Informaciâ 2, 3 I-7.

Mak, W., Tribushinina, E. \& Andreiushina, E. (2013). Semantics of connectives guides referential expectations in discourse: an eye-tracking study of Dutch and Russian. Discourse Processes 5o, 557-76.

McGregor, K. K. \& Appel, A. (2002). On the relation between mental representation and naming in a child with specific language impairment. Clinical Linguistics and Phonetics I6, I-20.

Meisel, J. M. (2007). The weaker language in early child bilingualism: acquiring a first language as a second language. Applied Psycholinguistics 28, 495-5 I 4.

Mirman, D., Dixon, J. A. \& Magnuson, J. S. (2008). Statistical and computational models of the visual world paradigm: growth curves and individual differences. Fournal of Memory and Language 59, 475-94.

Montgomery, J. W. \& Leonard, L. B. (r998). Real-time inflectional processing by children with specific language impairment: effects of phonetic substance. Fournal of Speech, Language, and Hearing Research 4I, I 432-43.

Montgomery, J. W. \& Leonard, L. B. (2006). Effects of acoustic manipulation on the real-time inflectional processing of children with Specific Language Impairment. Fournal of Speech, Language, and Hearing Research 49, I $238-56$.

Nash, M. \& Donaldson, M. L. (2005). Word learning in children with vocabulary deficits. Fournal of Speech, Language, and Hearing Research 48, 439-58.

Paradis, J. (I 999). What do specifically-language impaired and second language children have in common? Child Language Bulletin 19, 4-6.

Paradis, J. (20I0a). Bilingual children's acquisition of English verb morphology: effects of language dominance, structure difficulty, and task type. Language Learning 6o, 65 I-80.

Paradis, J. (20I ob). The interface between bilingual development and specific language impairment. Applied Psycholinguistics 31, 227-52.

Paradis, J. \& Crago, M. (2000). Tense and temporality: similarities and differences between language-impaired and second-language children. Fournal of Speech, Language, and Hearing Research 43, 834-48. 
Paradis, J., Rice, M. L., Crago, M. \& Marquis, J. (2008). The acquisition of tense in English: distinguishing child second language from first language and specific language impairment. Applied Psycholinguistics 29, 689-722.

Schilperoord, J. ( 1996 ). It's about time: temporal aspects of cognitive processes in text production. Amsterdam: Rodopi.

Schlyter, S. (1993). The weaker language in bilingual Swedish-French children. In K. Hyltemstam \& A. Viberg (eds), Progression and regression in language: sociocultural, neuropsychological and linguistic perspectives, 289-308. Cambridge: Cambridge University Press.

Schlyter, S. \& Håkansson, G. (r994). Word order in Swedish as the first language, second language and weaker language in bilinguals. Scandinavian Working Papers on Bilingualism 9, 49-66.

Sheng, L. \& McGregor, K. K. (2010). Lexical-semantic organization in children with specific language impairment. Fournal of Speech and Hearing Research 53, I46-59.

Swerts, M. (1998). Filled pauses as markers of discourse structure. Fournal of Pragmatics 30, $485-96$.

Tribushinina, E., Dubinkina, E. \& Sanders, T. (2015). Can connective use differentiate between children with and without SLI? First Language 35, 3-26.

Tribushinina, E., Mak, W. M., Andreiushina, E., Dubinkina, E. \& Sanders, T. (2015). Connective use in the narratives of bilingual children and monolingual children with SLI. Bilingualism: Language and Cognition. Online: doi: I0.10I7/S 366728915000577.

Tribushinina, E., Valcheva, E. \& Gagarina, N. (in press). Acquisition of additive connectives by Russian-German bilinguals: a usage-based approach. In J. Evers-Vermeul \& E. Tribushinina (eds), Usage-based approaches to language acquisition and language teaching. Berlin \& New York: Mouton.

Trueswell, J. C. \& Papafragou, A. (2010). Perceiving and remembering events crosslinguistically: evidence from dual-task paradigms. Fournal of Memory and Language 63, $64-82$.

Windsor, J. (2002). Contrasting general and process-specific slowing in language impairment. Topics in Language Disorders 22, 49-6I.

Windsor, J., Milbrath, R. L., Carney, E. J. \& Rakowski, S. E. (200I). General slowing in language impairment: methodological considerations in testing the hypothesis. Fournal of Speech, Language, and Hearing Research 44, 446-61. 